\title{
TIMING OF HYPOPHYSATION PROCESSES IN THE SUVER CARP HYPOPHTHALMICHTHYS MOLITRIX (VALENCIENNES) AND AN ATTEMPT TO EMPLOY THE CONCEPT OF LATENCY TIME
}

\author{
Amin A. EL-GAiMAL \\ Department of Animal Production, Faculty of Agriculture, \\ Ain Shams University, Egypt
}

Key Words: silver carp, hypophysation, induced breeding, latency time, reproductive traits.

\section{ABSTRACT}

The objectives of the present work were to study the ovulatory
response of silver carp when induced to breed using carp pituitary powder as an ovulation stimulator at various hours of the day. Furthermore, an attempt was carried out to determine the natural latency time, i.e. degree-hours hoping that it would be possible to employ it in carp hatchery procedures. Therefore, two experiments were carried out; in the first, the response to hormonal stimulation and the reproductive performance of female carps received a decisive injection with a spawning stimulator at different day times: 04.00 p.m., 08.00 p.m. and 11.00 p.m. was evaluated. In the second experiment, an estimate for the latency time in terms of degree hours was determined by placing preovulating females with fertilizing males and measuring the time elapsed till the natural spawning occurred. The relevance of this measured time was then tested in artificially induced spawning females groups.

The results revealed that percentage of ovulated females was higher $(100 \%)$ in the group received the decisive pituitary injection at 04.00 p.m. than those received it at 08.00 p.m. and 11.00 p.m. (87.5\% and $93.8 \%$, respectively). Injection time, however, had no effect on weight and quality of the obtained eggs when assessed in terms of percentages of fertilization, survival rates and percentage of deformed larvae. Nevertheless, combining results from ovulation and incubation success (spawning effectiveness coefficient) showed that injection time affected egg quality. The present results showed that the best overall quality of the sexual products was produced when female silver carps received the decisive injection at 04.00 p.m. when compared to those received it at 
either 08.00 p.m. or 11.00 p.m. The measured natural latency time was approximately $7.4 \mathrm{~h}$ which is equivalent to $188.4 \pm 1.99$ degree hours at a constant water temperature of $25.5^{\circ} \mathrm{C}$, although the latency time of artificially spawned females was $199 \pm 1.74$ degree hours under the same conditions. The presence of males with the spawning female groups significantly $(\mathrm{P}<0.05)$ increased the percentage of ovulated females from $92.2 \%$ to $100 \%$ and decreased the average latency time of the spawning females by approximately 24 minutes.

\section{INTRODUCTION}

- Induced breeding in fish is a long and laborious process that may beextend over 20 hours, during which time a large numbers of workers has to be alert overnight. This is normally not convenient in commercial hatchery operations, where timing of the necessary spawning stages is critical to avoid employing a large number of workers outside the normal working hours. As such, timing of induced breeding is usually arranged to minimize the required work. On the other hand, Bieniarz et al. (1985) reported that maturational response of oocytes in carps to gonadotrpins, both in vivo and in vitro, was found to fluctuate in a daily rhythm, being maximal $9 \mathrm{~h}$ after the onset of the photophase. The latter authors found that pituitary homogenate injected at 9 a.m. resulted in a higher ovulation response than when injected at 9 p.m. Early studies (Hontela \& Peter, 1978; Brain \& William, 1979) showed daily cycles or fluctuations in serum gonadotropin levels in the gold fish at the time of gonadal maturation which makes the timing of injection more critical and complicated than may be originally thought. Therefore, it was important to clarify whether the ovulatory response of silver carp to hypophysation, under Egyptian conditions; differs when treatment is given at various hours of the day.

On the other hand, correct timing of females' stripping in relation to hypophysation proved to be critical for obtaining good sexual products and it is increasingly so when temperature is high (Horváth et al., 1984; Billard, 1999). After hypophysation, the females are usually stripped when free-running eggs can first be obtained by exerting slight pressure on their abdomen. When this procedure was used, however, a large prupurlion of eggs may be lost as they slept out from the genital opening. Additionally, the quality of eggs stripped in this manner is usually variable and occasionally increased percentages of deformed fry may be observed (Hogendoorn \& Vismans, 1980). The latter problem is related 
to the time between hypophysation and stripping. This period is called the latency or response time which may be directly affecting the degree of egg maturation (Xu Pao et al., 2003) and normally varies bctrveen 6- 8 hours in carps (Sarder et al. 2002; Xu Pao et al. 2003) when. hypophysation (the ovulation stimulator is a carp pituitary) is employed, although a much longer latency time $(14-16 \mathrm{~h}$ ) was reported when other ovulation stimulators are utilized e.g., LHRH-a (Brzuska, 2003; Arabacı et al., 2004). The ability of precisely predicting the moment of ovulation. is of prime importance, it can help avoiding the risks of getting premature or overripe ova (Brain \& William, 1979). One of the simplest ways of detecting the moment of ovulation is by placing a male with the spawning females; the male begins to demonstrate spawning behavior and closeiy follows the female from the moment ovulation occurs. It has been shown in many fish species that males are able to assess the reproductive status of females and alter their behaviour accordingly (Almeida et al., 2005). Nevertheless, this method is tricky as fish may spawn naturally in the spawning tanks before being caught leading to a considerable loss of ova. However, the latency of the response to artificial propagation in cyprinids has only been reported in general terms (Drori et al., 1994; and Yaron, 1995). Hence, Kucharczyk et al. (1997) suggested that before any spawning recommendations can be made to fish breeders, the dose of hormones and the precise timing in relation to water temperature had to be studied under local conditions. Since latency time is strongly correlated with water temperature (Hogendoorn \& Vismans, 1980; Drori $\cdot$ et al. 1994; Xu Pao et al. 2003) it is often measured as degree hours, i.e. the latency time in hours multiplied by the temperature $\left({ }^{\circ} \mathrm{C}\right)$. The temperature sum, i.e. degree hours, between the decisive injection and ovulation in the silver carps is not known in Egypt.

The objectives of the present work were: 1) to clarify whether the ovulatory response of silver çarp varies when fish are treated at various hours of the day; 2) to determine the precise latency period as a function of temperature in silver carp under Egyptian conditions, i.e., degree-hours in relation to the spawning results. It is probably possible that such an investigation will, hopefully, help in refining the timing and the technique of artificially spawning of Chinese carps in Egypt. 


\section{MATERIALS AND METHODS}

The present study comprises two experiments that were carried out during the period lasted from May to June 2005 at a private fish hatchery located at Waddy El-Natron, approximately $100 \mathrm{~km}$ from Cairo. The experimental fish were all selected from a large broodstock (several hundred fish) kept for almost one year in earthen ponds where they were allowed for an area of approximately $20 \mathrm{~m}^{2} /$ fish. The earthen fish ponds were regularly fertilized with organic manure along with low doses of single super-phosphate (15 kg per hectare) at fortnightly intervals. Approximately $13 \%$ of the water of these ponds was exchanged daily with artisan well water and the overflow water of a tilapia hatchery. Water quality was around the following criteria: Oxygen, not less than $3.5 \mathrm{mg} / \mathrm{l} ; \mathrm{pH}, 7.6$; Total ammonia nitrogen, not more than $0.07 \mathrm{mg} / 1$; Total alkalinity, $420 \mathrm{mg} / \mathrm{l}$ as calcium carbonate; Total hardness, $380 \mathrm{mg} / \mathrm{l}$ as calcium carbonate. Water temperature during the experimental work (indoors) was in the order of $25.5^{\circ} \mathrm{C}$.

\section{Experiment 1:}

To investigate the effect of day time injection on the response of females to ovarian stimulation, three experimental groups (I, II and III), each containing 8 ripe female brooders, were induced to breed at different day times. An equal number of males was also selected but were kept isolated from females and treated as the procedure mentioned below. Each of the present experimental groups was injected for breeding in a different time, group I received the first injection at 07.00 a.m., whilst groups II and III received the first injection at 11.00 a.m. and 02.00 p.m., respectively. The time of the second injection in each group was arranged to be 9 hours later, i.e. the decisive injections were administrated at 04.00 p.m., 08.00 p.m. and 11.00 p.m., respectively. The experimental design of this experiment is illustrated in Table (1).

Ripe females were distinguished by the enlargement and rèlaxation of the back part of the abdomen, the palpability of the outline of the gonads, the swollen pinkish genital opening and the presence or absence of pre-anal ridge (Horváth et al., 1984; Brzuska, 1999). For spawning, each breeding batch was transferred to a 3-m diameter concrete tank, which was continuously provided with flowing fresh water at a constant Iiow :ate that provided approximately $6 \mathrm{l} / \mathrm{min}$ per fish, so that it. maintained an oxygen level close to saturation. This water was derived from an artisan well, although it was firstly pumped to a header tank at which it was provided with strong aeration before being distributed to the 
spawning facilities. Water quality in the spawning tanks was of the following quality criteria: temperature, $25.5^{\circ} \mathrm{C}$; $\mathrm{pH}, 7.4$; Oxygen, $5-6.0^{\circ}$ $\mathrm{mg} / \mathrm{l}$; total ammonia nitrogen, $<0.05 \mathrm{mg} / \mathrm{l}$.

For hypophysation, experimental fish were lightly anaesthetized (MS 222, Argent Company, Philippines, Manila) in 1501 fiberglass tank, weighed and marked with a colored thread. Spawning female fish received two doses of carp pituitary powder, with an interval of $9 \mathrm{hrs}$ between the two injections. The preliminary dose was $0.3 \mathrm{mg} / \mathrm{kg}$, whilst the decisive one was $4 \mathrm{mg} / \mathrm{kg}$ body weight. The pituitary powder was suspended in a $0.7 \% \mathrm{NaCl}$ solution and the proper dose was injected deeply into the muscle below, but ahead of the top dorsal fin and above the Iateral line region. The fertilizing males were injected with $3 \mathrm{mg}$ pituitary powder $/ \mathrm{kg}$ body weight at the time when the females were receiving the first injection. The brood fish were then transferred back into the spawning concrete tanks, and during the next 6 hours they were left undisturbed at a constant temperature of $25.5^{\circ} \mathrm{C}$, after which time brooder fish were observed closely to monitor ovulation time. Once. spawning females were in estrus, they were immediately captured, lightly anaesthetized and stripped. The stripped eggs were released from the ovaries into clean, dry and previously weighed plastic bowls by a gentle massage with slight pressure on the lower sides of the females from front to back until the ovaries were empty or when a drop of blood appeared. The obtained eggs were immediately weighed and a sample of approximately one gram of dry eggs was then taken and the number of eggs was carefully counted (Rothbard, 1981) to obtain an estimate for the number of eggs per $\mathrm{kg}$. Fertilization was accomplished using the "dry" method, i.e. the milt was added directly into the plastic bowl by stripping a male brooder. Eggs and milt were then gently stirred by a goose feather for a minute to ensure that they were thoroughly mixed. Few minutes later, eggs were rinsed several times and $600 \mathrm{ml}$ of partially swollen fertilized eggs were transferred into each egg incubator (175 liter). This amount of eggs allowed a total number of hatched larvae in the order of 100,000. Dead eggs were siphoned off several times a day to keep all jars. clean and to avoid bacterial and fungal infections, and a protective dose of formalin (150-200 ppm) was applied every $6 \mathrm{hrs}$ during the first 36 hours of incubation. Eggs usually hatch in about 20 hours in water at 25.5 ${ }^{\circ} \mathrm{C}$. The percentage of fertilization was calculated after $12 \mathrm{~h}$ incubation period, whilst those of the live embryos and deformed larvae were calculated after $48 \mathrm{~h}$. Sampling of these sexual products was carried out 
according to Rothbard (1981). Spawning success was evaluated according to Kucharczyk et al. (1996) using the spawning effectiveness coefficient $(S e)$; where ( $S e=O s \times I s)$, Os denotes ovulating success (Number of ovulating females / Total number of injected females) and Is represents incubation success (Number of live embryos / Total number of embryos).

Experiment 2:

A total of 36 female brood fish, manifesting signs of maturity, with an average body weight of $3.80 \mathrm{~kg} \pm 0.40$, were allocated into two experimental groups: A and B. The first group (A) comprised of 24 fish divided into 3 batches of 8 fish each, whilst the second group (B) included 12 fish divided into 3 batches of brooders, each consisted of 4 fish. The three batches of group (A) were all induced to breed within 3 days at a rate of one group a day along with one batch of group $B$, according to the procedure mentioned above.

The experimental group (B) was intended to provide a guide line for ovulation timing, hoping that it will determine the best stripping time for group (A). Fish of group (B) were treated in a similar manner to group (A), but two males were placed with each batch after the administration of the decisive injection. The purpose of these males was to check the ovulating females and encourage them to spawn, marking the natural latency time under the prevailing environmental conditions. It was initially intended to compare the performance of the natural spawning (i.e., spawning of group $B$ ) with the artificial spawning that practiced in group (A), but this procedure was abundant later because of the difficulty of collecting all the eggs produced from the large spawning tanks in an accurate way. Special attention was continuously paid to fish in the two experimental groups. The injected females of both experimental groups (A \& B) were left undisturbed after the second injection for 6 hours, after which time water level in the spawning tanks was lowered so that water depth was just enough to cover the dorsal fin of the spawning fish, although water flow was maintained at the same rate. The outflow water of the spawning tanks was received on a dark cloth to check for any reproductive materials that may be produced. At the time of natural ovulation, females in estrous of group (B) showed anxiety, circling the spawning tank while males were following and touching them. Once a single spawning occurred in group (B), the natural latency time was recorded and brood fish of group (A) were then immediately captured and checked for ovulation by applying a gentle pressure on fish abdomens. 
Responsive fish were gently stripped and the latency time was recorded, in a degree hour's term. If the fish were not in ovulating stage, they were replaced in the spawning tank and re-examined after 45 minules to determine the observed latency time. Wrong determination in timing $\mathrm{o}$ stripping showed a number of sequences similar to that described by Rothbard (1982) in common and Chinese carps. Usually, ripened spawn i.e. neither overripe nor removed ahead of the correct time, flows freely when a gentle massage was applied on the abdomen. The color of the eggs varied from olive-green (the common color in good quality eggs) to brownish green and appeared to be very sticky. If the stripping was slightly late, the overripe eggs lose their characterized stickiness and contain some ovarian fluids. On the other hand, if stripping is performed too early, the fish will release no eggs or very few eggs flow intermittently at times having a reddish color due to internal injuries to blood vessels, and when fertilized, the embryos develop regularly but the hydration was not uniform, resulting in the mortality of embryos prior to hatching.

Statistical analyses

Data of the A batches of the second experiment were pooled with experimental group III of the first one, where fish received their first injection at the same time $(02.00 \mathrm{p} . \mathrm{m}$.). Therefore, the number of fish considered in the first experiment was 48 fish with an average $3.80 \pm 0.49$ $\mathrm{kg}$ body weight. The pooled data were analyzed (unequal number analysis of variance) to examine the effect of injection time on the percentage of spawning females and other reproductive characteristics. Prior to ANOVA, values expressed as percentages were transformed. using arcsine transformation. The analysis was then followed by a Duncan's multiple-range test for multiple mean comparisons. The following traits were assessed: percentage of ovulated brooders, latency time $(d h)$, weight of eggs as a percentage of body weight of females (GS), percentage of fertilized eggs, percentage of living embryos and percentage of deformed larvae as well as spawning effectiveness coefficient $(S e)$. Various relationships among the evaluated traits were performed using a regression programme (Zar, 1974). Data obtained from the second experiment was presented as means and standard deviations.

\section{RESULTS}

Results of experiment 1 are summarized in Table (2) that shows the spawning characteristics of the three experimental groups of silver carps 
induced to breed at different day times, whilst that of experiment 2 are illustrated in Table (3) that shows the spawning characteristics of silver carp groups induced to breed in the presence and absence of fertilizing males.

\section{Percentage of spawning females after hormonal stimulation}

The results revealed that percentage of ovulated females in group I, which received the first carp pituitary injection at 07.00 a.m. (i.e. the injection was at 04.00 p.m.) was significantly $(\mathrm{P}<0.05)$ higher $(100 \%)$ than those of the other two batches ( $87.5 \%$ and $93.75 \%)$, for group II and III, which received decisive injections at 08.00 p.m. and 11.00 p.m., respectively (Fig. 1), although the latter groups were not different from each other $(\mathrm{P}>0.05)$ (Table 2). On the other hand, results of experiment 2 showed that the presence of males with the spawning female groups significantly $(\mathrm{P}<0.05)$ increased the percentage of ovulated females from $92.19 \%$ to $100 \%$ (Fig. 2 ).

\section{Latency period}

In experiment 1 , a latency period of $206.4 \pm 1.17$ degree hours (approximately $8 \mathrm{~h}$ ) was observed for group $\mathrm{I}$, where females were injected at 07.00 a.m. (Table 2). This period was longer $(\mathrm{P}<0.05)$ than those recorded for the other experimental groups (II and III), 198.0 \pm 2.83 and $198.4 \pm 1.57$ (7.8 and $7.9 \mathrm{~h}$ ), respectively (Fig. 3). On the other hand, the average natural latency time (for females spawned naturally in the presence of males) observed in the present study (group B) was 188.4. \pm 1.99 degree hours (equivalent to approximately $7.4 \mathrm{~h}$ ) at a constant water temperature of $25.5^{\circ} \mathrm{C}$ (Table 3). This was less $(\mathrm{P}<0.05)$ than that observed in average latency time recorded for females of group A (199.6 \pm 1.74 , group A). The presence of males shortened the average latency time of the spawning females by approximately 24 minutes. This result is illustrated in Fig. (4).

\section{Weight and quality of the obtained eggs}

No significant effect $(P>0.05)$ was observed for the injection time on egg weights expressed as a percentage of female body weight, i.e. gonado-somatic index, GSI (Table 2). Furthermore, injection time had no effect $(P>0.05)$ on both fertilization percentages and survival rates or on the percentage of deformed larvae (Figs. 6, 7 and 8, respectively). Attho gh, no significant differences in individual egg quality traits have been observed between the three experimental groups that were injected at different times, the spawning effectiveness coefficient ( $\mathrm{Se}$ ) detected significant variations $(\mathrm{P}<0.05)$ among them (Table 2, Fig. 5). The highest 
value of $S e$ was recorded in group I $(0.78 \pm 0.01)$ compared with that calculated for the second II and third III group (0.69 \pm 0.00 and 0.73 \pm 0.01 ), respectively.

\section{Dependencies between the investigated parameters}

The coefficients of correlation among the investigated parameters calculated for the different groups are given in Table (4). The correlation between female body weights and the egg weights presented in grams exhibited a positive significant value $(0.60)$, for fish of the three investigated groups I, II and III of experiment 1 . However, when a similar relationship was estimated but with egg weights expressed as percentage of female body weight (GSI) a low negative value $(-0.10)$ was estimated (Table 4). On the other hand, a significant negative correlation was detected between the latency time and fertilization rate $(-0.60)$, coefficient of determination, $R^{2}=0.36$, although there was a positive correlation between latency time and the percentage of the observed deformed larvae (0.60).

\section{DISCUSSION}

The response of female carps received their first injection at 07.00 a.m. was significantly higher than that of brooders given their preparatory injection at either 11.00 a.m. or 02.00 p.m. indicating that injection time is an effective factor in carp hypophysation. These findings support that reported by Bieniarz et al. (1985) who showed that pituitary homogenate injected in carps at 9 a.m. resulted in a higher ovulation response in carp than when injected at 9 p.m. The authors attributed these results to the daily rhythmic fiuctuations in gonadotropins associated with the natural photophase cycles, and suggested that maximum daily rhythm of gonadotropins occurred after $9 \mathrm{~h}$ after the onset of the photophase. In the present study, highest female response was also observed in the experimental group that received the decisive injection after almost $9 \mathrm{~h}$ after the onset of the photophase, i.e. the priming injection was at 07.00 a.m. In an earlier study, Hontela \& Peter (1978) demonstrated daily cycles in serum gonadotropin levels in mature gold fish and showed that certain daily fluctuations in the gonadotropin levels at the time of maturation occurred as a response to certain environmental factors that include photoperiod and temperature. However, the rhythm of such gonadotropin fluctuations and the factor(s) affecting it in silver carp was beyond the scope of the present study, but a research in this direction is justifiable. 
It is interesting to notice that the presence of males with the spawning female in experiment 2 increased the percentage of ovulated females and decreased the average latency time period of the spawning females by approximately 24 minutes, in average. Chemical communication is widely believed to be important during reproduction in teleosts (Pinillos et al., 2003). Séveral fish species have been shown to possess pheromonal activities (Stacey \& Sorensen, 2002). The presence of male fish with preovilatory females is known to mutually affect sexual activity of both sexes in a number of fish species (Miranda et al., 2005). For example; in female sticklebacks (Gasterosteus) spawning was possible only after being for two or three days in the vicinity of a male stickleback engaged in nest-building (Smith, 1982). Further, in Arctic char males release PGF $_{2 \alpha}$ into water to attract females and stimulate their spawning behaviour (Sveinsson \& Hara, unpublished data after Evans, 1993). Furthermore, Pheromones released by male fishes may be steroids (or their metabolites), and may function on attract females or cause them to ovulate (van Den Hurk and Resink, 1992), or to coordinate reproductive events in other males (Sherwood et al., 1991). The existence of such mechanisms in. silver carps can't be excluded, although experimentation in this direction is needed to prove such a postulation. Unfortunately, the chemicals and the sensory systems involved in the above mechanisms and their routes of release have not been rigorously investigated (Russock, 1990; Almeida et al,; 2005; Miranda et al., 2005).

Injection time affected the latency time which was longer in fish received the priming injection at 0.7 .00 a.m., when compared to those received this dose either at 11.00 a.m. or 02.00 p.m. $(8.09$ vs. 7.76 and 7.78, respectively). Similarly, the difference in latency time in the two experimental groups of experiment 2 was 7.4 and $7.8 \mathrm{~h}$; being shorter in the presence of males. The differences among the latter means. (in both experiments) were statistically significant $(\mathrm{P}<0.05)$, although the magnitude of these differences were apparently minimal from numerical point of view: This was because the sum of squares within each. experimental group was small, i.e. spawning.was highly synchronized in each spawning tank, allowing the $\mathrm{F}$ test to detect a significant difference among "treatments with very close mean values. Highly synchronized spawhing was frequently reported in carps (Arabacs, 2004; Brzuska, 2004), when spawning was stimulated with carp pituitary extracts but not. with different LHRH forms or their analogues (Brzuska, 2000). Brzuska (2004) reported cases in which complete ovulation synchronizations were 
recorded. It is of considerable importance for hatchery management that an induced breeding practice synchronizes ovulation in the treated females. It is worth mentioned that during the present study, spawning of a female in a breeding tank evokes a surge in spawning among other females in the same vicinity. This may be explained in the light of the secretion of certain types of prostaglandins by ovulating females. Evans (1993) explained that at the time of ovulation, females produce PGFs to mediate follicular repture and to trigger female spawning behaviour. Circulating PGFs are subsequently metabolized and released into the water, where they function as a postovulatory pheromone that stimulates male sexual arousal, thus resulting in spawning synchrony. Furthermore, it has been reported that ovulated females induce ovulation in other females only in the presence of males, suggesting the existence of bisexual primer pheromones (van Weerd and Richter, 1991). The above discussion may shed a light on the cause that shortened the latency time of spawning females in the presence of male spawners in the present work.

Latency time in Chinese carps, which is an important factor in the planning of spawning induction in fish, has been estimated by many authors under different environmental conditions and various ovarian stimulators (Peter et al., 1982; Drori et al., 1994; Bruzuska, 1999; 2003; Brzuska, \& Bialowas, 2002). Their estimations were largely in the range of 7-12 h but comparisons are not relevant due to variations in experimental conditions. Latency time as a function of temperature in common carp, silver carp, bighead carp and grass carp induced to spawn by carp pituitary was found to be negatively linear in the temperature range of $19-26^{\circ} \mathrm{C}$ (Billard, 1999). The negative correlation between latency time and water temperature is to be expected in poikilothermic animals in which the rate of metabolic process is dependent on the ambient temperature. Prolonged latency time was frequently reported, e.g., 19-32h (Brzuska \& Grzywaczewski, 1999), when ovarian stimulators other than carp pituitary extract were utilized, e.g. LHRH forms and their analogues (Kucharczyk et al., 1997; Arabact, 2004; Brzuska, 2003; 2004). In the present study (experiment 1) a prolonged latency time was observed in females received their first injection at 07.00 a.m. in comparison with that observed for spawners injected in later times. No decisive answer, however, can be given to this result. On the other hand, measuring latency time in presence of males with spawning females in the second experiment may give an outline for alarming that required for 
the artificially induced females. The measured natural latency time was approximately $7.4 \mathrm{~h}$ which is equivalent to $188.4 \pm 1.99$ degree hours at a constant water temperature of $25.5^{\circ} \mathrm{C}$. However, the precise latency time required was found to exceed the measured one by approximately 24 minutes at a temperature of $25.5^{\circ} \mathrm{C}$, although more experimentation is probably needed to verify this estimate. Another important finding was that the presence of males had a positive effect on the extent of females' response and in reducing latency time. Since placing males with spawning females is risky, as they may spawn naturally, other methods to utilize the present finding should be considered. This may imply placing them in the female spawning tanks with a net barrier or recycle the outflow waters from both females and males spawning tanks to each other.

Injection time had no effect on egg weight, expressed as a percentage of female body weight (GSI), or on egg quality judged by individual traits, i.e. percentage of fertilization, survival rates or by the percentage of deformed larvae. However, the spawning effectiveness coefficient ( $\mathrm{Se}$ ) combining results from ovulation and incubation success detected significant variations among the experimental treatments (Table .2 , Fig. 5). The latter coefficient scored a higher significant value for group I, where females were injected at 07.00 a.m. when compared with that of the other experimental groups $I I$ and III, where females were injected at 11.00 a.m. and 02.00 , respectively. According to this criterion, all the latter 3 experimental groups were different from each other, indicating that injection time affecting egg quality. Although the best overall quality of the sexual products is produced when female silver carps received the prime injection at the early moming (07.00 a.m.), their latency time was longer. Further studies, measuring the hourly fluctuations. in gonadotropin levels under different environmental conditions, are certainly required to verify the present results. Furthermore, the present results emphasized that spawning effectiveness coefficient ( $\mathrm{Se}$ ) is probably a more reliable estimate for evaluating sexual products than evaluating individual traits independently. The values obtained in the present research were in the range of 0.69 to 0.78 which were comparable to that obtained in several other studies, e.g., 0.60 to 0.72 reported by Kucharczyk et al. (1996). For cyprinds, Se values over 0.5 are regarded good results (Thalathiah et al., 1988; Kucharczyk et al., unpublished data after Kucharczyk et al., 1996). 
The correlation between female body weights and weight of eggs presented in grams was characterized by a positive significant value of 0.60 , for fish in the three investigated groups, however a low negative value $(-0.10)$ was estimated when egg weights were expressed as a percentage of female body weight (GSI). Similar findings were reported (Brzuska \& Bialowas, 2002) and were discussed elsewhere (El-Gamal, 2006). A significant negative correlation was detected between the latency time and fertilization rate $(-0.60)$, although there was a positive correlation between latency time and the percentage of deformed larvae (0.60). This is in agreement with that reported by Kozlowski (1994) in cyprinid fishes and Kucharczyk et al. (1997) in bream, Abramis brama. Working with different strains of the carp Cyprinus carpio, Brzuska (2004) reported that the above relationship is valid for some strains (Hungarian strain) but not with others (French strain). The latter authors described a comparable relationship between egg quality expressed as a percentage of fertilized eggs and latency time. They concluded that the biological quality of eggs originating from "late" ovulation (when the time elapsed from resolving injection to ovulation was long) was poor.

\section{CONCLUSION}

The timing of administration of gonadal stimulators in. hypophysation of silver carps is an effective factor that not only affects the percentage of ovulating females but also the quality of their sexual products. Spawning fish received a priming injection at 07.0 a.m. (i.e. the decisive injection at 04.00 p.m.) showed a higher response to the hormonal treatment and their overall reproductive performance was better than those received it at either 8 p.m. or 11.00 p.m. The natural latency time in silver carps when a hypophysation technique was employed is $188 \pm 1.99$ (degree hours). The presence of males with the spawning females enhanced their response to the hormonal treatment and shortened their latency time by approximaltely 24 minutes (i.e. 199.6 \pm 1.74 degree hours). The spawning effectiveness coefficient $(S e)$ is probably a more reliable estimate for evaluating sexual products 'of carps than evaluating individual traits independently. Based on the obtained results it is recommended to start hypophysation procedures (the priming injection) at 07.00 a.m. and to start egg collection after 199.6 degree hours, when the prevailing conditions are similar to that of the present study. 


\section{REFERENCES}

Almeida, O. G.; Miranda, A.; Frade, P.; Hubbard, P. C.; Barata, E. N. and Canário, A.V.M. (2005). Urine as a social signal in the Mozambique' tilapia (Oreochromis mossambicus). Chem.Senses (Suppl. 1), 30: 309-310.

Arabacı, M.; Cağrgan, H. and Sart, M. (2004). Induction of ovulation in ornamental common carp (Koi, Cyprinus carpio L.) using LHRHa ([D-Ser(tBu) ${ }^{6}$, Pro $\left.\left.^{9}-\mathrm{Net}\right]-\mathrm{LHRH}\right)$ combined with haloperidol and carp pituitary extract. Aqucul.Res., 35: 10-14.

Bieniarz, B.; Popek, W.; Breton, B. and Epler P. (1985). Daily changes in the gonadotropin levels and response of carp oocytes to hypophysial homogenate. Chronobiol. Int., 2:93-101.

Billard, R. (1999). Carp: Biology and Culture. In: R. Billard (ed). Praxis Publishing Ltd, Chichester, London, Uk.

Brain, H. and William, H.S. (1979). The theory and practice of induced breeding in fish. Ottawa, Ont., IDRC, FAO, 48 pp.

Brzuska, E. (1999). Artificial spawning of herbivorusc fish: use of an LHRH-a to induce ovulation in grass carp Ctenopharyngodon idella (Valenciennes) and silver carp Hypophthalmichthys molitrix (Valenciennes). Aquacul. Res., 30:849-856.

Brzuska, E. (2000). Artificial spawning of carp Cyprinus carpio L.: differences between the effects on reproduction in females of Polish and Hungarian provenance treated with carp pituitary and (D-Ala ${ }^{6}$ ) GnRH ProNHEt (Kobarelin). Aquacul.Res., 3I: 457465.

Brzuska, E. (2003). Artificial spawning of female Polish line 3 carp (Cyprinus carpio L.) after treatment with pituitary homogenate and/or Ovopel. Aquacul.Res., 34: 1321-1327.

Brzuska, E. (2004). Artificial spawning of carp (Cyprinus carpio L.); differences between the effects of reproduction in females of Hungarian, Polish and French origin treated with carp pituitary 
homogenate or [D-Tle6, ProNHEt9] GnRH (Lecirelin). Aquaculture Res., 35: 1318-1327.

Brzuska, E. and Bialowas, H. (2002). Artificial spawning of carp, Cyprinus carpio (L.). Aquaculture Res., 33: 753-765.

Brzuska, E. and Grzywaczewski, R. (1999). Artficial spawning of carp (Cyprinus carpio L.): differences between the effects on reproduction in females of Israeli strain Dor-70 and its crossbred treated with carp pituitary and Ovopel. Aquacul.Res., 30: 559570.

Drori S.; Ofir M.; Levavi-Sivan B. and Yaron, Z. (1994). Spawning induction in common carp (Cyprinus carpio) using pituitary extract or GnRH superactive analogue combined with. metoclopramide: analysis of hormone profile, progress of oocyte maturation and dependence on temperature, Aquacult, 119: 393407.

El-Gamal, A. A. (2006). Artificial spawning of the Chinese herbivorous carps: use of $\mathrm{HCG}$ to induce ovulation in silver carp Hypophthalmichthys molitrix (Val.). (Under publication).

Evans, D.H. (1993). The Physiology of Fishes. By Evans, David H., CRC series in marine science, CRC Press, Inc., Boca Raton, Florida $33431.590 \mathrm{pp}$.

Hogendoorn, H. and Vismans, M.M. (1980). Controlled propagation of the African catfish, Clarias lazera (C. \& V.). II. Artificial reproduction. Aquacult, $21: 39-53$.

Hontela, A. and Peter R.E. (1978). Daily cycles in serum gonadotropin levels in the gold fish: effects of photoperiod, temperature and sexual condition. Cand. J. Zool. 56; 2430-2442.

Horváth, L.; Támas, G. and Tölg, I. (1984). Special Methods in Pond Fish Husbandary. In: J.E. Halver (ed) Halver Corporation, Seattle, USA. 
Kozlowski, B. (1994). Practice of hormonal stimulation of artificial spawning in cyprinid fishes. Broszura Instytutu Rybactwa Srodladowego (Olsztyn) 162: 41pp.

Kucharczyk, D.; Kujawa, R.; Mamcarz, A.; Skrzypczak, A. and Wyszomirska, E. (1.996). Induced spawning in perch (Perca fluviatilis L.) using carp pituitary extract and hCG. Aquacul.Res., 27:847-852.

Kucharczyk, D; Kujawa, R.; Luczynski, M.;. Glogwski, J; Babiak, I.; and Wyszomirska, E. (1997). Induced spawning in bream, Abramis brama (L.), using carp and bream pituitary extract and hCG. Aquacul.Res., 28: 139-144.

Miranda, A.; Almeida, O.G.; Hubbard, P.C.; Barata, E. N. and Canário, A.V.M. (2005). Olfactory discrimination of female reproductive status by male tilapia (Oreochromis mossambicus). J. of Expl. Biol., 208: 2037-2043.

Peter, R.E.; Paulenco, C.R. and B. Breton (1988). Temporal resposiveness of the ovary of gold dish to gonadotropin. J. Interdiscipl. Cycle Res., 13: 229-239.

Pinillos, M.L.; Guijarro, A.I.; Delgado, M.J.; Hubbard, P.C.; Canário, A.V.M. and Scott, A.P. (2003). Production, release and olfactory detection of sex steroids by the tench ( Tinca tinca L.). Fish Physiol. Biochem. 26:197 -210.

Rothbard, S. (1981). Induce reproduction -in cultivated cyprinids- the common carp and the group of Chinese carps. 1. The technique of induction, spawning and hatching. Bamidgeh, 33: 103-121.

Rothbard, S. (1982). Induced reproduction in cultivated Cyprinids - the common carp and the group of Chinese carps: II. The rearing of larvae and the primary nursing of fry, Bamidgeh 34:20-32.

Russock, H. I. (1990). The effect of natural chemical stimuli on the preferential behaviour of Oreochromis mossambicus (Pisces: Cichlidae) fry to maternal models. Behaviour 115:315 -326. 
Sarder, A.S.; Azan, M.R. and Hossain, M.A. (2002). Private hatchery owners' prospectives on hatchery management in Bangladesh. In: Penman D.J.; Hussain, M.G.; McAndrew, B.J. and M.A. Mazid (eds.). Proceedings of a workshop on Genetic Management and Improvement Strategies for Exotic Carps in Asia, 12-14 February 2002, Dhaka, Bangladesh. Bangladesh Fisheries research Institute, Mymensingh, Bangladesh. pp. 77-81.

Sherwood, N.M.; Kyle, A.; Kreiberg, H.; Warby, C.M.; Magnus, T.H.; Carolsfeld, J. and Price, W.S. (1991). Prtaial charcterisation of a spawning pheromone in the herring Clupea pallasi. Can. J. Zool., 69: 93.

Smith, L. S. (1982). Reproduction, Introduction to fish physiology, By L.S. Smith, T.F.H Publications, Inc., 352 pp.

Stacey, N. and Sorensen P. (2002). Hormonal pheromones in fish. In: NonMammalian Hormone-Behavior Systems, vol. 2 (eds.) D. W. Pfaff, A. P. Arnold, A. M. Etgen, S. E. Fahrbach and R. T. Rubin), pp.375 -434 . London: Harcourt Publishers Ltd/Academic Press.

Thalathiah, S; Ahmad, A.O. and Zaini, M.S. (1988). Induced spawning techniques practiced at Bàtu Berendam, Melaka, Malaysia. Aquacult. 7.4:23-33.

van Den Hurk, R. and Resink, J.W. (1992). Male reproductive systems as sex pheromone producer in teleost fish. J. Exp. Zool., 261: 204.

van Weerd, J.H. and C.J.J. Richter (1991). Sex pheromones and ovarian development in telẹost fish, Comp. Biochem. Physiol. A, 100: 517.

Xu Pao.; Kuanhong, M.; Jian, Z.; Jianxin, W. and Yongseng G. (2003). Comparative studies on spawning-inducing using Ovaprim and other hormones, hitt://www.syndel.com/spawning/ ovaprim-ffrc-report.html.

Yaron Z. (1995). Endocrine control of gametogenesis and spawning induction in the carp. Aquacult., 129: 49-73.

Zar, J.H. (1974). Biostatistical analysis. In: D. McElroy \& C.P. Swanson (eds). Biological Sciences Series, Printice-Hall, Inc., Englewood Cliffs, London. 
Table (1). The experimental design of experiment 1.

\begin{tabular}{lcccc}
\hline $\begin{array}{l}\text { Experimental } \\
\text { Group }\end{array}$ & $\begin{array}{c}\text { Females' } \\
\text { Numbers }\end{array}$ & $\begin{array}{c}\text { Time 1 } 1^{\frac{8}{2}} \\
\text { Injection }\end{array}$ & $\begin{array}{c}\text { Time } \\
\text { Injection }\end{array}$ & $\begin{array}{c}\text { Predicted Time } \\
\text { of Spawning }\end{array}$ \\
\hline Group I & 8 & $\mathbf{0 7 . 0 0 ~ a . m . ~}$ & 04.00 p.m. & 11.30 p.m. \\
Group II & 8 & 11.00 a.m. & 08.00 p.m. & 03.30 p.m. \\
Group III & 8 & $\mathbf{0 2 . 0 0}$ p.m. & 11.00 p.m. & 06.30 p.m. \\
\hline
\end{tabular}

Table (2). Spawning characteristics of silver carp induced to breed at different day times (Means \pm SE) in experiment 1.

\begin{tabular}{|c|c|c|c|c|c|c|c|c|}
\hline $\begin{array}{l}\text { Expl. } \\
\text { Groupl } \\
\text { Injection } \\
\text { Time }\end{array}$ & $\begin{array}{l}\text { Fish } \\
\text { Weight } \\
\text { kg } \\
\end{array}$ & $\begin{array}{l}\text { Degree } \\
\text { hourss }\end{array}$ & $\begin{array}{l}\% \\
\text { Ovilated } \\
\text { Femises }\end{array}$ & GS & $\begin{array}{c}\% \% \\
\text { Fertilization }\end{array}$ & $\begin{array}{c}\% \\
\text { Survival }\end{array}$ & $\begin{array}{c}\% \\
\text { Deformed }\end{array}$ & $\begin{array}{c}\text { Spawning } \\
\text { Coefficient } \\
\text { (Se) }\end{array}$ \\
\hline $7.0 \mathrm{~g} \mathrm{~m}$ & $\begin{array}{r}3.53 \\
\pm 0.57\end{array}$ & $\begin{array}{l}206.40^{\circ} \\
\pm 1.17\end{array}$ & $\begin{array}{c}100.00^{\circ} \\
\pm 0.0\end{array}$ & $\begin{array}{r}9.80 \\
\pm 0.46\end{array}$ & $\begin{array}{r}94.86 \\
\pm 0.68\end{array}$ & $\begin{array}{r}77.45 \\
\pm 0.58\end{array}$ & $\begin{array}{r}11.38 \\
\pm 0.61\end{array}$ & \\
\hline $\begin{array}{c}\mathrm{IV} \\
11.0 \mathrm{a} . \mathrm{m} .\end{array}$ & $\begin{array}{r}3.94 \\
\pm 0.59\end{array}$ & $\begin{array}{l}198.00^{5} \\
\pm 2.83\end{array}$ & $\begin{array}{c}87.50^{6} \\
\pm 0.0\end{array}$ & $\begin{array}{r}10.19 \\
\pm 0.54\end{array}$ & $\begin{array}{r}95.99 \\
\pm 0.49\end{array}$ & $\begin{array}{l}78.2 \mathrm{t} \\
\pm 0.45\end{array}$ & $\begin{array}{r}11.27 \\
\pm 0.79\end{array}$ & $\begin{array}{c}0.69^{\mathrm{b}} \\
\pm 0.00\end{array}$ \\
\hline $\begin{array}{c}\text { III/ } \\
2.0 \text { p.m. }\end{array}$ & $\begin{array}{c}3.81 \\
\pm 0.45\end{array}$ & $\begin{array}{c}198.41^{b} \\
\pm 1.57\end{array}$ & $\begin{array}{l}93.75^{b} \\
\pm 1.12\end{array}$ & $\begin{array}{r}9.79 \\
\pm 0.31\end{array}$ & $\begin{array}{r}94.68 \\
\pm 0.38\end{array}$ & $\begin{array}{l}77.95 \\
\pm 0.48\end{array}$ & $\begin{array}{r}10.89 \\
\pm 0.39\end{array}$ & $\begin{array}{r}0.73^{c} \\
\pm 0.01\end{array}$ \\
\hline
\end{tabular}

Means with the same letter are not statistically different $(P>0.05)$.

-Table (3). Spawning characteristics of silver carp induced to : breed in the presence and absence of males (Means \pm SE) in experiment 2.

\begin{tabular}{|c|c|c|c|c|c|c|c|c|}
\hline $\begin{array}{l}\text { Expl. } \\
\text { group }\end{array}$ & $\begin{array}{c}\text { Fish Weigh } \\
\mathrm{kg}^{\prime}\end{array}$ & $\begin{array}{c}\text { Latency } \\
\text { periad (dh) }\end{array}$ & $\begin{array}{c}\text { \%Ovulater } \\
\text { Femalk: }\end{array}$ & $\% G S I$ & $\begin{array}{c}\% \\
\text { Fertilizatio }\end{array}$ & $\begin{array}{c}\% \\
\text { Survival }\end{array}$ & $\begin{array}{c}\% \\
\text { Deformed }\end{array}$ & $\begin{array}{c}\text { Spawning } \\
\text { Coefficien } \\
(\mathrm{Se})\end{array}$ \\
\hline $\begin{array}{c}\text { A } \\
\text { Without } \\
\text { Males }\end{array}$ & $\begin{array}{c}3.80 \\
\pm 0.43\end{array}$ & $\begin{array}{l}199.61^{1} \\
\pm 1.74\end{array}$ & $\begin{array}{l}92.19^{\circ} \\
. \pm 1.26\end{array}$ & $\begin{array}{c}9.57 \\
\pm 1.70\end{array}$ & $\begin{array}{r}94.68 \\
\pm 1.98\end{array}$ & $\begin{array}{r}78.12 \\
+2.92\end{array}$ & $\begin{array}{r}10.89 \\
\pm 2.31\end{array}$ & $\begin{array}{c}0.72 \\
=0.05\end{array}$ \\
\hline $\begin{array}{c}\text { B } \\
\text { With Male: }\end{array}$ & $\begin{array}{c}3.79 \\
\pm 0.35\end{array}$ & $\begin{array}{c}188.37^{b} \\
\pm 1.99\end{array}$ & $\begin{array}{c}100.00^{6} \\
\pm 0.0\end{array}$ & $m$ & - & - & 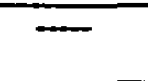 & - \\
\hline
\end{tabular}

Means with the same letter are not statistically different $(P>0.05)$.

Table (4). Coefficients of correlation between spawning characteristics of silver carp induced to breed at different day times.

\begin{tabular}{|c|c|c|c|c|c|c|c|c|}
\hline Variable & $\begin{array}{l}\text { Latenc } \\
\text { Time }\end{array}$ & $\begin{array}{l}\text { Eggs } \\
\text { Weight } \\
\text { (g) }\end{array}$ & $\begin{array}{l}\text { Eggs wt. } \\
\text { as\% of } \\
\text { body } \\
\text { weight }\end{array}$ & $\%$ GS & $\begin{array}{l}\% \\
\text { Fertilizatio }\end{array}$ & $\begin{array}{l}\text { \% } \\
\text { Survival }\end{array}$ & $\begin{array}{l}\text { \% } \\
\text { Deformed } \\
\text { Larvae }\end{array}$ & Se \\
\hline BW (kg) & -0.09 & $0.60^{*}$ & -0.12 & -0.10 & 0.09 & -0.20 & -0.11 & -0.12 \\
\hline $\begin{array}{c}\text { Latency } \\
\text { Time }\end{array}$ & -0.56 & 0.09 & -0.62 & $-0.60^{*}$ & -0.44 & $0.60^{*}$ & -0.22 \\
\hline GSI & & & & & 0.42 & 0.38 & -0.57 & 0.26 \\
\hline
\end{tabular}




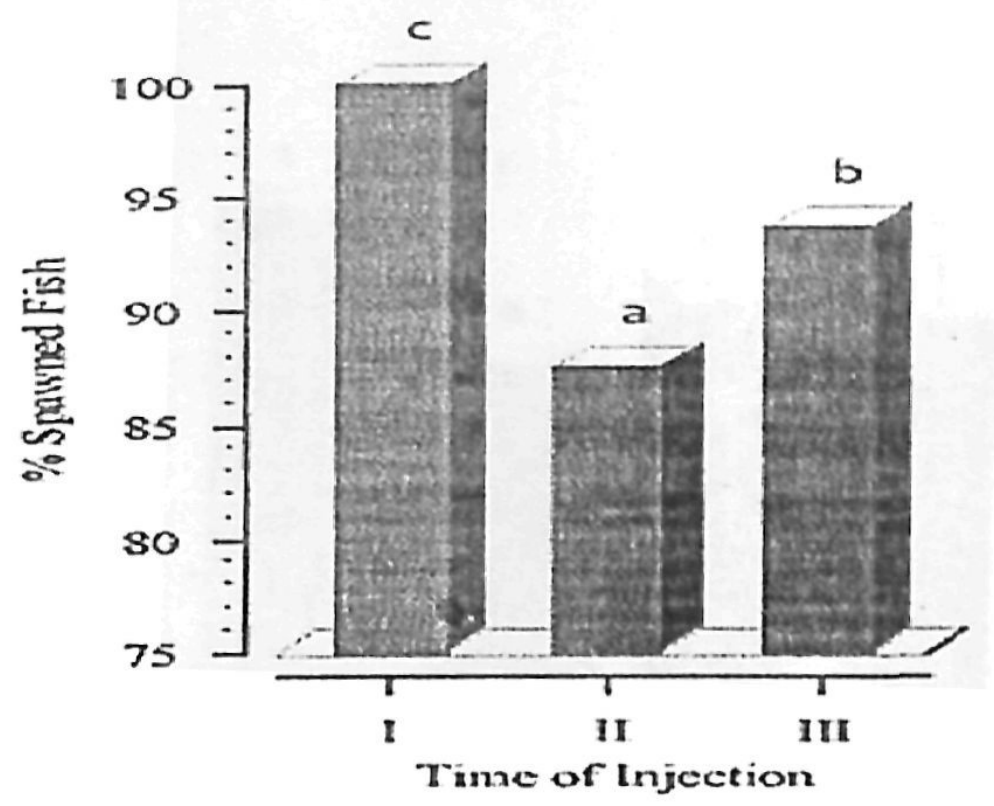

Fig. 1. Effect of injection time on the percentage of ovulated females. Bars with the same letter are not statistically different $(P<0.05)$.

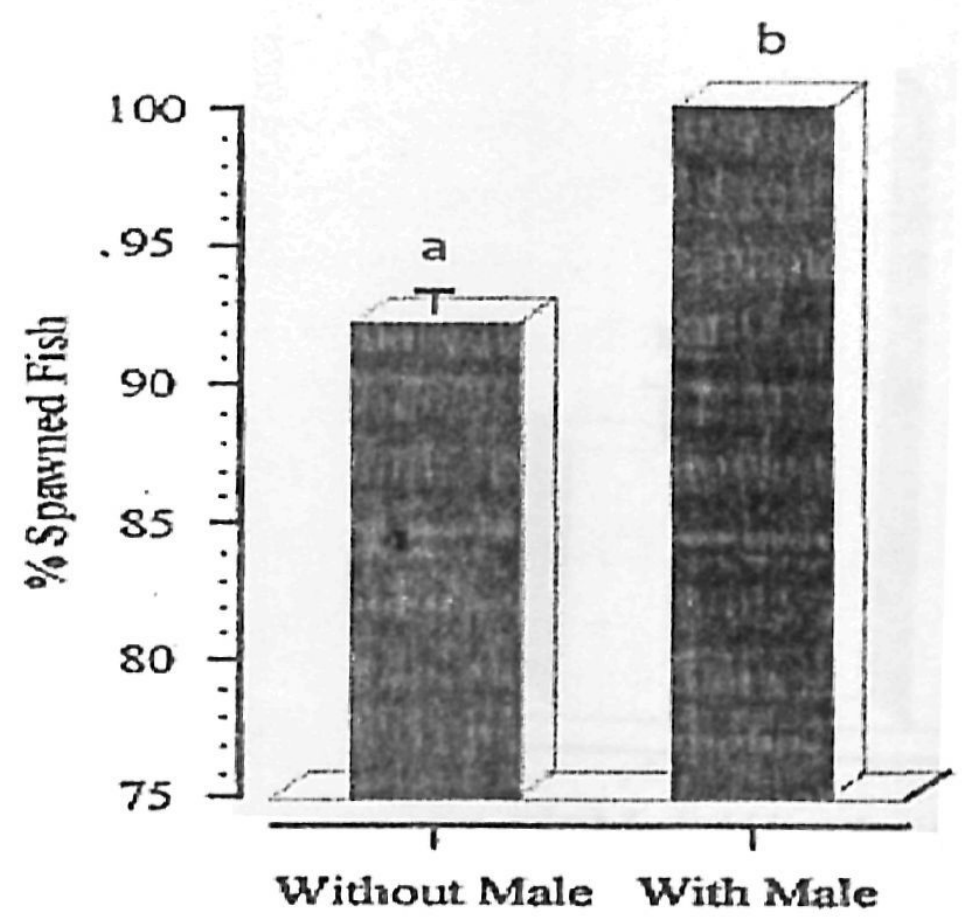

Fig. 2. The effect of male presence on the percentage of ovulated females. Bars with different letters are statistically different $(P<0.05)$. 

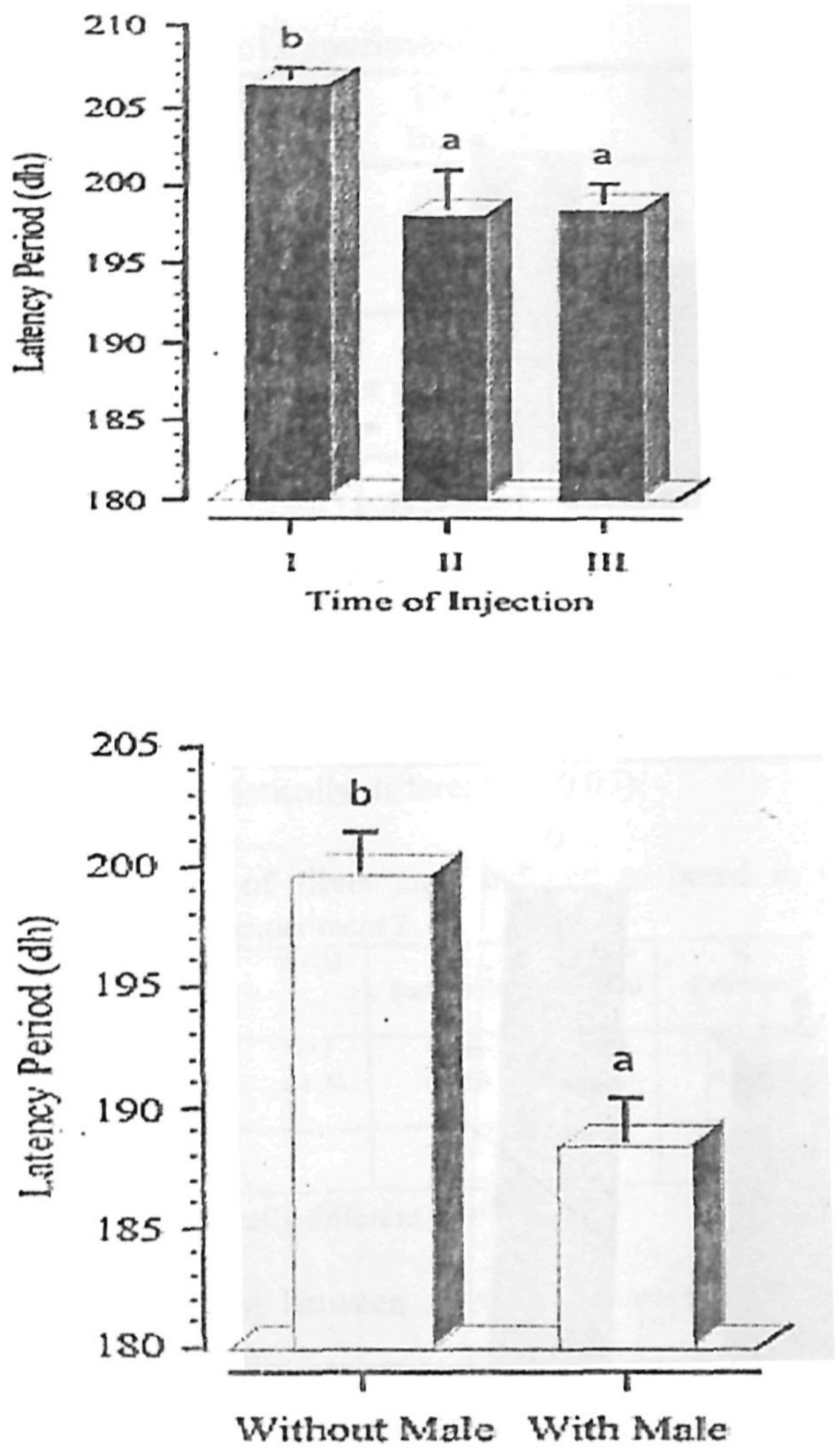

Fig. 4. The effect of males' presence on latency Time (degree hou Bars with different letters are statistically different $(\mathrm{P}<0.05)$. 


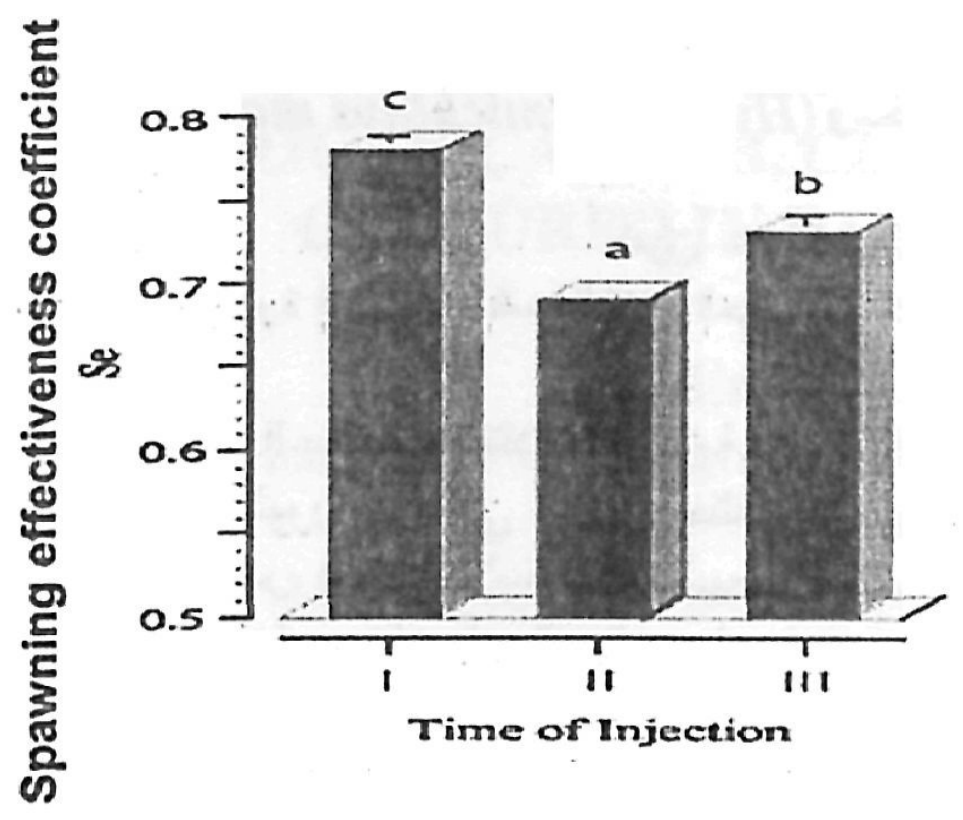

Fig. 5. Effect of injection time on the spawning effectiveness coefficient ( $\mathrm{Se})$. Bars with the same letters are not statistically different $(\mathrm{P}>0.05)$. 